\title{
Rancang Bangun Aplikasi Biro Travel dengan SMS Gateway dan Google Maps API
}

\author{
Muhammad Hazbiallah At Taufiq, Anita Hidayati \\ Jurusan Teknik Informatika dan Komputer \\ Politeknik Negeri Jakarta \\ m.hazbi.juve@gmail.com, anita.hidayati@tik.pnj.ac.id
}

Diterima: 8 Maret 2016. Disetujui: 14 April 2016. Dipublikasikan: Mei 2016

\begin{abstract}
Let's Go Outside Travel is a company engaged in the service. Services offered are open-trip travel and tours combined. Tours provided by the travel easier for customers to travel schedules and facilities that are already programmed. The technology can help this is to develop a web-based system for travel agencies Let's Go Outside in the promotion. To meet the demands of the importance of managing the data do the booking, the travel party decided to create a web application that serves to promote new tourism by using google maps API, add a photo documentation and facilitate the process of confirming the transaction with SMS Gateway technology. These include web application design business processes in the travel Let's Go Outside. This design using waterfall method. This method uses a real way and clear for every step of the manufacturing system. The web applications created using CodeIgniter framework, the application has been undergoing testing stages. The results showed that the application has been successfully meeting the user needs with the success rate is $85.7 \%$ of 13 respondents.
\end{abstract}

Keywords: open trip; SMS Gateway; Code igniter; waterfall; Google Maps API

\section{PENDAHULUAN}

Informasi merupakan kebutuhan mendasar bagi setiap perusahaan pada saat sekarang ini. Informasi memungkinkan perusahaan dapat terus berkembang dan bersaing dengan perusahaan lain. Dewasa ini, sistem informasi berfokus pada sistem informasi berbasis komputer dengan harapan penggunaan teknologi informasi khususnya komputer dapat menghasilkan informasi lebih akurat, berkualitas dan tepat waktu sehingga dapat lebih efektif dan efisien.

Perkembangan teknologi informasi menjadi semakin maju. Adanya kemajuan teknologi informasi memungkinkan penyusunan dan pengaturan pola kerja yang tertata dengan baik dan rapi. Kemajuan teknologi informasi juga memungkinkan penyajian, pencarian dan pengecekan data selalu siap kapanpun dibutuhkan sehingga tidak lagi dibatasi oleh waktu.

Traveling merupakan aktivitas berpindah dalam satu tempat ke tempat lainnya dengan tujuan untuk bisnis, liburan dan sebagainya. Biro travel Let's Go Outside merupakan usaha yang berjalan di bidang travel dengan menyediakan jadwal perjalanan untuk pelanggan yang ingin melakukan traveling. Perjalanan bisnis pada Let's Go Outside selama ini masih menggunakan media pemasaran dengan cara manual kepada para pelanggan. Dengan kemajuan teknologi informasi saat ini, maka Let's Go Outside membutuhkan sebuah web yang penting untuk pemasaran maupun promosi kepada pelanggan dengan tepat, cepat, dan efisien dari sisi waktu dan biaya.

\section{TINJAUAN PUSTAKA}

A. Short Message Service (SMS) Gateway

SMS Gateway adalah suatu sistem yang menjembatani antara handphone dengan sistem yang menjadi server dengan SMS sebagai informasinya. SMS Gateway tidak memerlukan koneksi internet manapun karena sifatnya memang bekerja sendiri. SMS Gateway memerlukan satu atau beberapa buah terminal. Pemilihan banyak terminal akan menjadikan pengiriman dan penerimaan SMS semakin cepat.[1]

Menurut Azkalfikri [2] SMS Gateway adalah sebuah perangkat lunak yang menggunakan bantuan komputer dan memanfaatkan teknologi seluler yang diintegrasikan guna mendistribusikan pesan-pesan yang di-generate lewat sistem informasi melalui media SMS yang di-handle oleh jaringan seluler. Beberapa kemampuan SMS Gateway, yaitu untuk:

1) Memperbesar skala aplikasi teknologi informasi dengan menggunakan komunikasi SMS interaktif.

2) Menyediakan aplikasi kolaborasi komunikasi SMS berbasis web untuk pengguna di institusi atau perusahaan.

\section{B. Google Maps API}

Google Maps adalah layanan gratis Google yang cukup populer. Fitur Google Maps dapat ditambahkan dalam web dengan Google Maps API. Struktur Google Maps API sendiri sudah menjadi library JavaScript [3]. Untuk dapat menggunakan 
Google Maps pertama pengembang harus terlebih dahulu mendapatkan Google Maps API Key di developers console milik Google. Cara kerja Google Maps yaitu dengan menggunakan teknologi HTML, CSS, dan JavaScript yang merupakan teknologi dasar untuk sebuah web [4]. Google Maps sebenarnya hanya terdiri dari gambar-gambar potongan peta yang ditampilkan di halaman web. Saat user melakukan navigasi di Google Maps maka koordinat dan tingkat zoom akan diperbarui lalu Google Maps akan mengirimkan gambar peta sesuai dengan kedua faktor tersebut [5]. Gambar 1 menunjukkan implementasi dari Google Maps API.

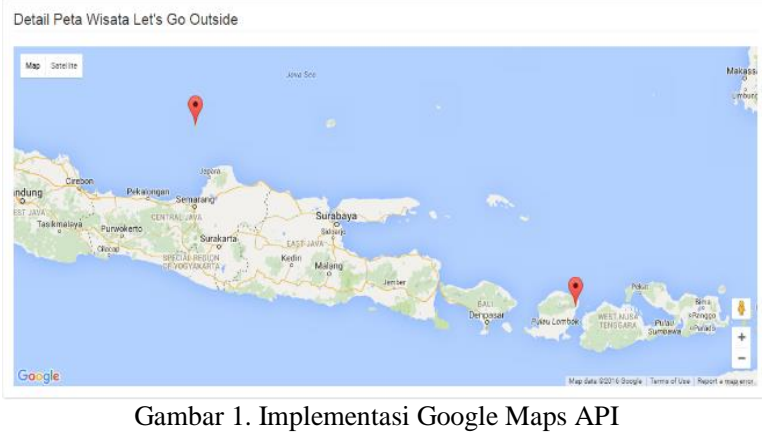

\section{Biro Travel}

Menurut Yoeti [6] biro travel adalah suatu perusahaan yang memperoleh pendapatan dan keuntungan dengan menawarkan dan menjual produk serta jasa-jasa pelayanan yang diberikannya kepada pelanggannya. Biro travel memiliki beberapa peran, yaitu:

- Pengurusan dokumen travel

- Ticketing (penjualan tiket pesawat domestik dan internasional)

- Hotel Reservation (dalam dan luar negeri)

- Agen perjalanan kapal pesiar, charter flight, kapal laut dan kereta api

- Paket wisata untuk dalam dan luar negeri

- Escort services (jasa mengiringi)

- Jemput dan antar tamu dari dan ke bandara

- Pelayanan Umroh, Ibadah Haji dan perjalanan rohani lainnya.

Open Trip adalah suatu trip atau tour yang pesertanya digabung dengan peserta lain dengan jadwal yang sudah ditentukan oleh biro travel dan menggunakan kuota minimal untuk keberangkatan. Paket open trip merupakan paket wisata yang sudah memiliki rundown dengan jelas dari pihak biro travel.

Contohnya traveller ingin melakukan wisata ke Karimun Jawa dengan biaya tempat wisata keseluruhan 9 juta. Sangat mahal jika ditanggung satu orang. Di sisi lain Let's Go Outside membuat wisata ke Karimun Jawa dengan biaya 1,5 juta untuk 6 orang. Traveller yang ingin berwisata ke Karimun Jawa dapat bergabung dengan Let's Go Outside guna membantu mengurangi biaya dengan sambil menunggu kuota 6 orang terpenuhi. Jika sudah terpenuhi maka traveller hanya tinggal menunggu jadwal keberangkatan sesuai dengan yang sudah ditentukan pihak Let's Go Outside. Traveller juga hanya tinggal mengikuti jadwal yang sudah dibuat oleh pihak Let's Go Outside.

\section{PERANCANGAN PROGRAM APLIKASI}

Perancangan program adalah proses yang dilakukan sebelum membuat aplikasi. Proses perancangan yang dilakukan pada sebuah aplikasi dapat berupa perancangan mock up, alur kerja, atau basis data. Pada proses ini juga dipertimbangkan siapa saja pengguna dari aplikasi. Dalam rancangan program aplikasi digunakan tahapan metode waterfall yang terdiri dari rekayasa perangkat lunak, analisa kebutuhan, desain sistem, implementasi, pengujian, dan pemeliharaan. Output dari setiap tahap merupakan input bagi tahap berikutnya.

\section{A. Deskripsi Program Aplikasi}

Aplikasi berbasis web ini digunakan untuk pemasaran dan promo kepada pelanggan dari biro travel Let's Go Outside. Data informasi dari web disimpan ke dalam database menggunakan MySQL. User yang dapat masuk ke bagian dashboard adalah user admin dan user super admin. Fungsi user admin ialah untuk menambahkan informasi yang akan ditampilkan dalam web Let's Go Outside, baik itu wisata, foto maupun artikel. Fungsi user super admin adalah melakukan konfirmasi pembelian tiket tour yang dilakukan oleh pelanggan dengan memanfaatkan SMS Gateway. Selain melakukan konfirmasi, super admin juga dapat melihat data pemesanan pelanggan.

\section{B. Cara Kerja Program Aplikasi}

Gambar 2 merupakan proses yang dilakukan Admin jika memilih menu detailwisata. Admin akan melihat halaman detailwisata dan dapat melakukan 3 aktivitas, yaitu menambahkan detailwisata baru, mengubah dan menghapus detailwisata. Jika admin memilih tambah detail wisata maka sistem akan memproses inputan admin. Jika tidak, maka admin akan mengubah detailwisata yang ada dan sistem akan memproses aktivitas ubah yang dilakukan oleh admin. Jika tidak, admin akan menghapus detailwisata yang kemudian sistem akan memproses untuk menghapus detailwisata yang sudah ada. Proses menambahkan data lain seperti yang ada pada menu fasilitas, menu album foto, menu gallery dan menu pegawai hampir sama dengan proses yang ada pada detail wisata.

Pada gambar 3 merupakan halaman contact us dari admin. Contact us pada halaman ini berisikan data seputar pertanyaan yang diajukan oleh pelanggan. Pada menu contact us admin dapat melakukan aktivitas membuat/membalas pertanyaan 
ke pelanggan dan menghapus pertanyaan yang ada, kemudian sistem akan memproses aktivitas yang dilakukan oleh admin.
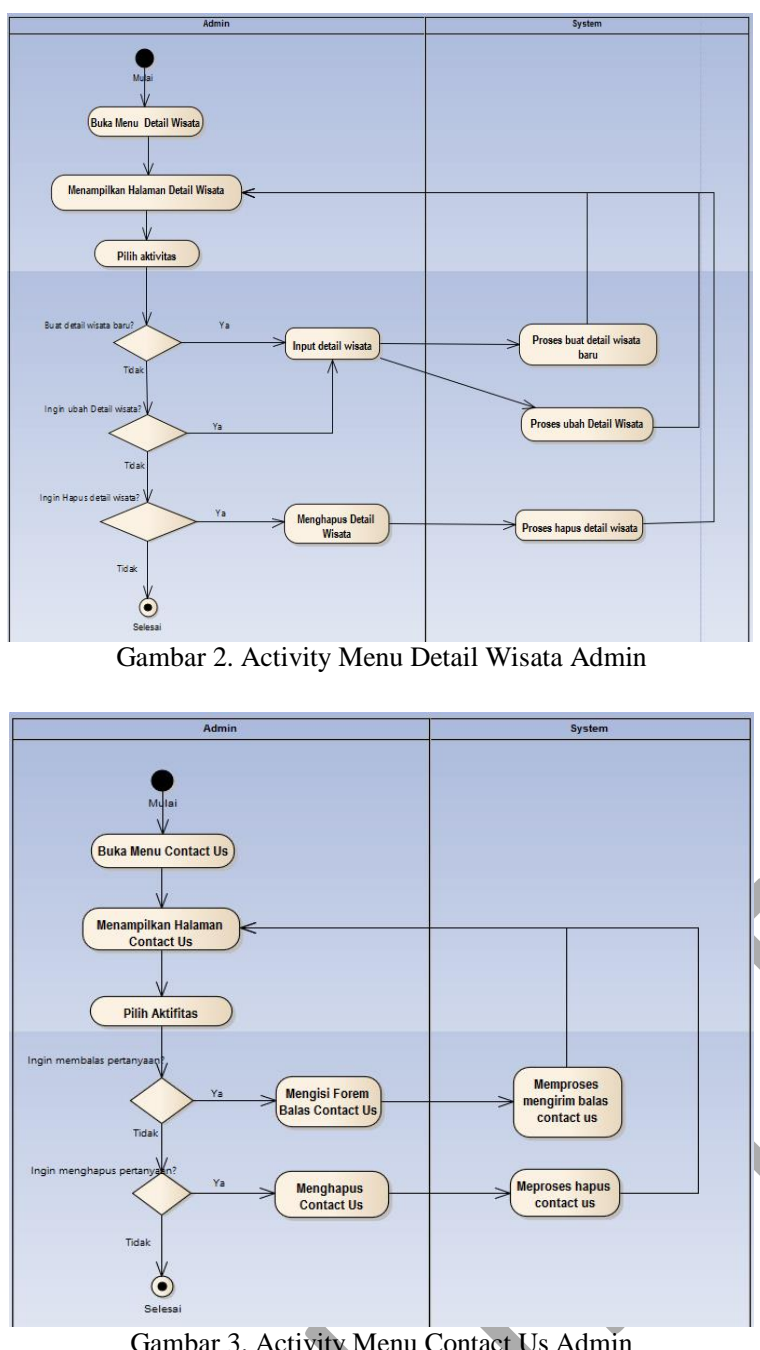

Gambar 3. Activity Menu Contact Us Admin

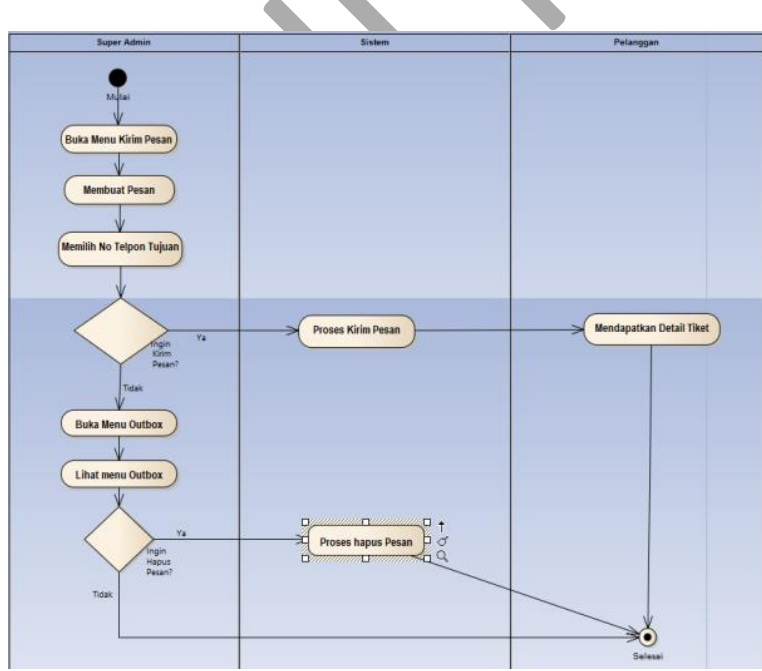

Gambar 4. Activity Menu Kirim Pesan dan Outbox

Pada menu kirim pesan di Gambar 4, super admin dapat menulis pesan layaknya di smartphone.
Jika sudah menulis pesan, maka super admin dapat memilih nomor tujuan yang sebelumnya sudah dibuat pada menu phonebook. Kemudian proses pengiriman pesan akan melalui sistem yang kemudian pesan akan diterima oleh pelanggan. Super admin dapat melihat pesan terkirim atau tidak, admin dapat menuju ke halaman menu outbox yang berisikan data pengiriman SMS kepada pelanggan.

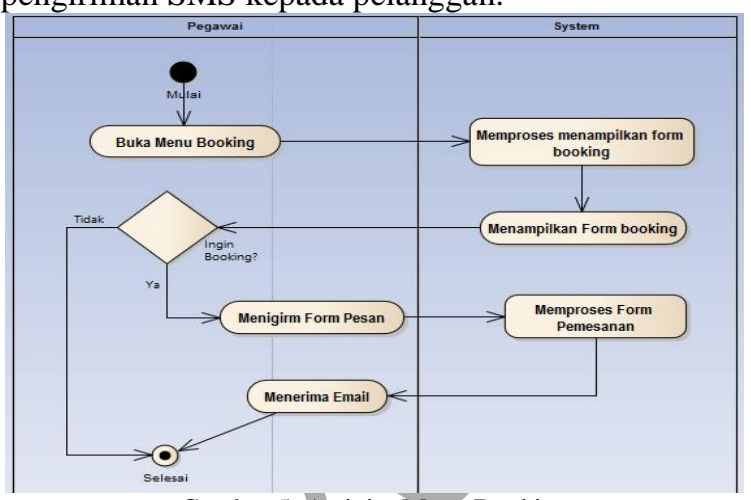

Gambar 5. Activity Menu Booking

Pelanggan yang ingin melakukan booking wisata dapat memilih menu booking dengan mengisi form yang tersedia. Kemudian pelanggan akan mendapatkan balasan email otomatis dari Let's Go Outside yang berisikan mengenai detail booking dan tata cara konfirmasi pembayaran. Langkah-langkah booking terdapat pada Gambar 5.

Aktor admin merupakan pihak biro travel Let's Go Outside yang bertugas melakukan penambahan paket tour. Bagian Admin merupakan pihak biro travel Let's Go Outside yang bertugas melakukan konfirmasi pembayaran paket tour dan superadmin merupakan pihak yang melakukan pemesanan paket tour dan juga pembayaran paket tour pada web travel Let's Go Outside. Use case admin terdapat pada Gambar 6 dan super admin pada Gambar 7. Bagian Admin merupakan pihak biro travel Let's Go Outside yang bertugas melakukan konfirmasi pembayaran paket tour dan superadmin merupakan pihak yang melakukan pemesanan paket tour dan juga pembayaran paket tour pada web travel Let's Go Outside.

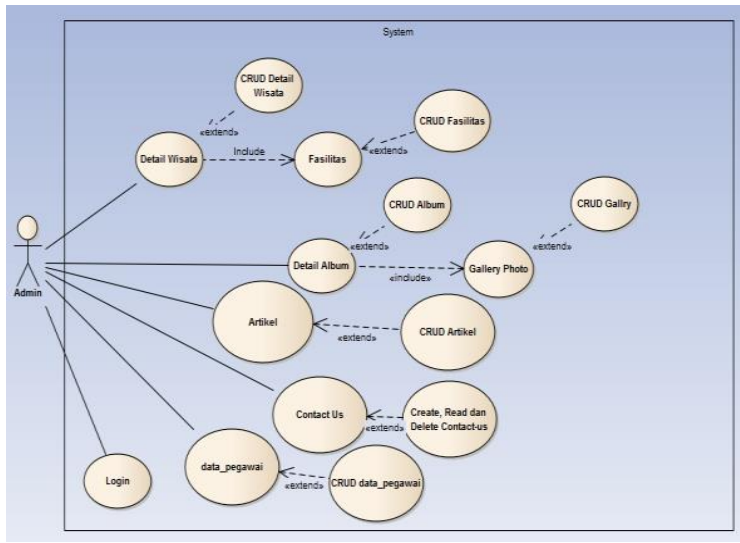

Gambar 6. Use Case Admin 


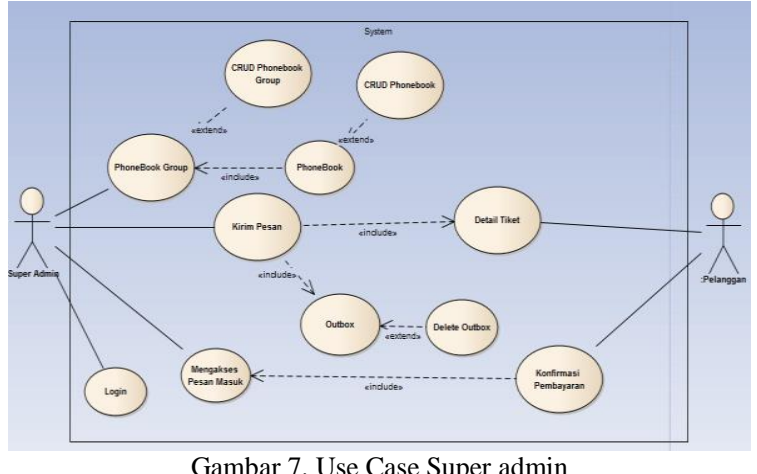

C. Realisasi Program Aplikasi

Gambar 8 merupakan implementasi dari antarmuka halaman login. Pegawai yang dapat mengakses halaman ini hanyalah user yang bertugas sebagai admin dan super admin.
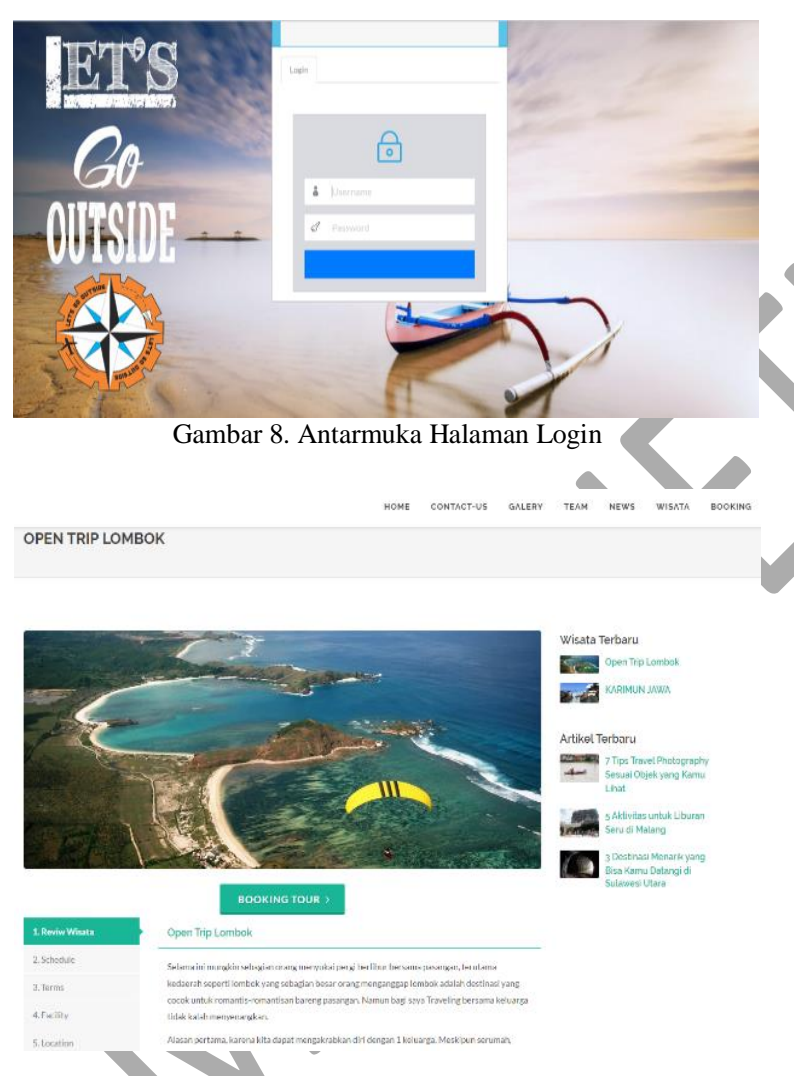

Gambar 9. Implementasi Antarmuka Detail Wisata Pelanggan

Gambar 9 menampilkan detail wisata yang dipilih oleh pelanggan. Bagian sidebar berisi wisata terbaru dan artikel terbaru. Pelanggan dapat langsung memilih tombol booking bila tertarik untuk memesan wisata. Terdapat 5 menu tab accordian yang berisi review wisata, schedule, term, fasilitas dan location. Bagian awal detail wisata menampilkan menu tab review wisata yang berisi ulasan tentang tempat wisata tersebut.
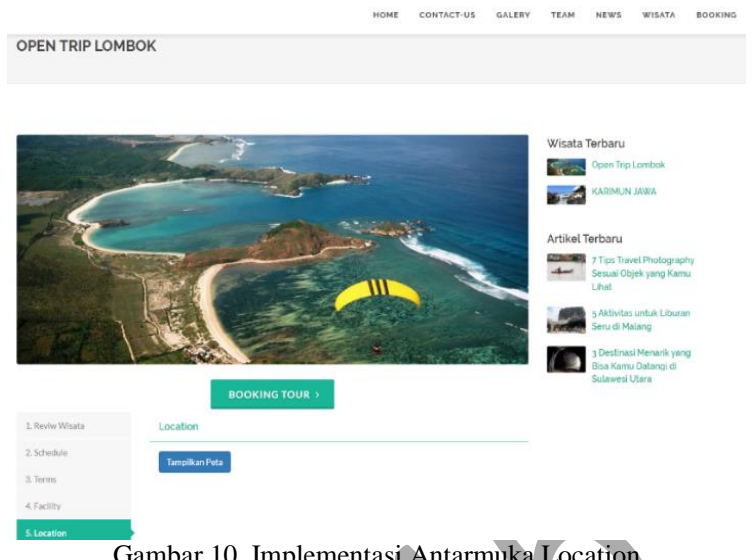

Gambar 10. Implementasi Antarmuka Location

Gambar 10 menampilkan menu tab location pada detail wisata. Menu tab ini memiliki perbedaan dengan menu tab lainnya. Jika pada menu tab lainnya menampilkan kata-kata, maka pada menu tab location ini hanya ada satu buat tombol yang akan mengarahkan pelanggan kepada peta wisata Let's Go Outside. Pada Gambar 11 menampilkan peta yang terdapat marker dari tempat wisata pada Let's Go Outside. Jika diklik gambar marker maka akan muncul alamat lokasi tempat wisata tersebut.

PETA WISATA LET'S GO OUTSIDE

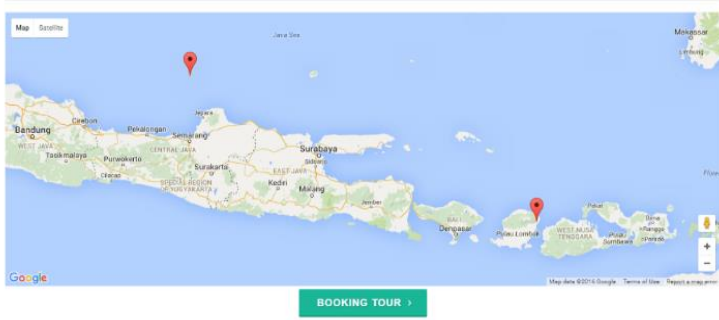

Gambar 11. Implementasi Antarmuka Peta Wisata

IV. PENGUJIAN

Pengujian sistem dilakukan ketika sistem telah selesai dikembangkan. Pada tahap ini, sistem diuji apakah telah memenuhi syarat dan sesuai untuk diterapkan. Sistem lolos uji jika semua fungsi dalam sistem berjalan sesuai dengan yang diharapkan. Pengujian dilakukan untuk mengetahui apakah sistem sudah berjalan dengan baik dan berjalan dengan kebutuhan awal yang telah dirancang. Pengujian dilakukan dengan cara menguji sistem manajemen persediaan berdasarkan fitur yang sudah disediakan.

\section{A. Deskripsi Pengujian}

Pengujian aplikasi ini menggunakan metode pengujian Black Box. Pengujian Black Box digunakan untuk menguji fungsi-fungsi khusus dari aplikasi yang dirancang. Terdapat dua tahapan pengujian yang akan dilaksanakan yaitu tahap pengujian alpha dan beta. 


\section{B. Prosedur Pengujian}

Pengujian alpha adalah pengujian yang bertujuan untuk memastikan bahwa aplikasi yang diuji dapat berjalan dengan lancar tanpa gangguan error atau bug. Pada tahap pengujian ini penguji yang dilibatkan adalah sesama pengembang aplikasi yang mengerti cara kerja aplikasi dan mengetahui sumber error atau bug secara teknis. Prosedur pengujian alpha terdapat di Tabel 1 .

TABEL 1. PROSEDUR PENGUJIAN ALPHA

\begin{tabular}{|c|c|}
\hline Item Uji & Detail Pengujian \\
\hline \multirow[t]{2}{*}{ Modul Login } & Verifikasi Username \\
\hline & Verifikasi Password \\
\hline \multirow[t]{4}{*}{ Modul Detail Wisata } & Create Detail Wisata \\
\hline & Read Detail Wisata \\
\hline & Update Detail Wisata \\
\hline & Delete Detail Wisata \\
\hline \multirow[t]{4}{*}{ Modul Fasilitas } & Create Fasilitas \\
\hline & Read Fasilitas \\
\hline & Update Fasilitas \\
\hline & Delete Fasilitas \\
\hline \multirow{3}{*}{ Modul Contact } & Create Contact \\
\hline & Read Contact \\
\hline & Update Contact \\
\hline \multirow{4}{*}{ Modul Pegawai } & Create Data Pegawai \\
\hline & Read Data Pegawai \\
\hline & Update Data Pegawai \\
\hline & Delete Data Pegawai \\
\hline \multirow[t]{4}{*}{ Modul Artikel } & Create Artikel \\
\hline & Read Artikel \\
\hline & Update Artikel \\
\hline & Delete Artikel \\
\hline \multirow[t]{4}{*}{ Modul Album Foto } & Create Album Foto \\
\hline & Read Album Foto \\
\hline & Update Album Foto \\
\hline & Delete Album Foto \\
\hline \multirow[t]{4}{*}{ Modul Foto } & Create Foto \\
\hline & Read Foto \\
\hline & Update Foto \\
\hline & Delete Foto \\
\hline \multirow{4}{*}{ Modul Phonebook Gr } & Create Phonebook Group \\
\hline & Read Phonebook Group \\
\hline & Update Phonebook Group \\
\hline & Delete Phonebook Group \\
\hline \multirow{4}{*}{ Modul Phonebook } & Create Phonebook \\
\hline & Read Phonebook \\
\hline & Update Phonebook \\
\hline & Delete Phonebook \\
\hline \multirow[t]{3}{*}{ Modul Kirim Pesan } & Create Kirim Pesan \\
\hline & Read Pesan Masuk \\
\hline & Delete Pesan Masuk \\
\hline \multirow{2}{*}{$\begin{array}{l}\text { Modul Profile } \\
\text { Modul Booking }\end{array}$} & Update Profile \\
\hline & Create Booking \\
\hline
\end{tabular}

Pengujian beta adalah pengujian yang lebih mengutamakan kesiapan aplikasi yang dikembangkan sebelum diluncurkan ke pengguna yang sesungguhnya. Salah satu yang diujikan pada tahap pengujian ini adalah kualitas saat menggunakan aplikasi oleh user. Pengujian ini dapat dinilai dengan menggunakan kuesioner yang diberikan kepada para penguji. Setiap pertanyaan pada kuesioner memiliki nilai jawaban dengan skala dari 1 sampai 5.
Hasil kuesioner yang akan menentukan hasil pengujian beta secara keseluruhan.

1) Apakah desain tampilan dari web Let's Go Outside sudah cukup baik?

2) Apakah penataan letak dan ukuran teks di web Let's Go Outside sudah cukup baik?

3) Seberapa besar tingkat kemudahan dalam penggunaan aplikasi?

4) Seberapa cepat waktu yang diperlukan web Let's Go Outside untuk menampilkan data detail wisata atau detail artikel?

5) Apakah informasi detail wisata yang ada di web Let's Go Outside sudah sesuai dengan yang anda inginkan?

6) Apakah menu-menu yang ada pada web Let's Go Outside mudah dipahami?

7) Apakah tampilan peta lokasi dapat membantu anda mengetahui tempat wisata yang ada pada web Let's Go Outside?

8) Apakah form pemesanan sudah dapat membantu anda dalam melakukan pemesanan tempat wisata yang diinginkan?

Berdasarkan pengujian alpha dan beta yang sudah dilakukan, dapat dicari hasil jawaban dari kedua pengujian tersebut. Contoh salah satu hasil pengujian Alpha terdapat pada Tabel 2.

TABEL 2. PENGUJIAN FUNGSIONAL PADA MODUL LOGIN

\begin{tabular}{|l|l|c|}
\hline \multicolumn{1}{|c|}{ Skenario } & Hasil yang diharapkan & Kesimpulan \\
\hline $\begin{array}{l}\text { Jika username dan } \\
\text { password tidak diisi } \\
\text { dan klik tombol } \\
\text { login }\end{array}$ & $\begin{array}{l}\text { Sistem akan menolak } \\
\text { akses login dan akan } \\
\text { menampilkan tulisan } \\
\text { "gagal login" }\end{array}$ & Valid \\
\hline $\begin{array}{l}\text { Jika hanya mengisi } \\
\text { username dan } \\
\text { password tidak diisi }\end{array}$ & $\begin{array}{l}\text { Sistem akan menolak } \\
\text { akses login dan } \\
\text { menampilkan tulisan } \\
\text { "gagal login" }\end{array}$ & Valid \\
\hline $\begin{array}{l}\text { Jika hanya mengisi } \\
\text { password dan } \\
\text { username tidak diisi }\end{array}$ & $\begin{array}{l}\text { Sistem akan menolak } \\
\text { akses login dan } \\
\text { menampilkan tulisan } \\
\text { "gagal login" }\end{array}$ & Valid \\
\hline $\begin{array}{l}\text { Jika mengisi } \\
\text { username atau } \\
\text { password yang salah }\end{array}$ & $\begin{array}{l}\text { Sistem akan menolak } \\
\text { dan menampilkan } \\
\text { tulisan "gagal login" }\end{array}$ & Valid \\
\hline $\begin{array}{l}\text { Jika mengisi } \\
\text { username dan } \\
\text { password yang } \\
\text { benar }\end{array}$ & $\begin{array}{l}\text { Sistem menerima } \\
\text { akses login dan akan } \\
\text { masuk ke halaman } \\
\text { dashboard }\end{array}$ & Valid \\
\hline \multicolumn{2}{|l|}{ Pengutian } \\
\hline
\end{tabular}

Pengujian beta telah dilakukan dengan menggunakan sepuluh responden yang memiliki perangkat android dan sudah menginstall aplikasi dari sistem ini ke perangkat mereka. Kriteria penilaian skornya sendiri menggunakan skala likert dengan ketentuan pada Tabel 3.

TABEL 3. SKOR PRESENTASE NILAI

\begin{tabular}{|l|l|}
\hline \multicolumn{1}{|c|}{ Presentase } & \multicolumn{1}{c|}{ Keterangan } \\
\hline $0 \%-19,99 \%$ & $\begin{array}{l}\text { STS (Sangat tidak setuju, buruk atau } \\
\text { kurang sekali) }\end{array}$ \\
\hline $20 \%-39.99 \%$ & TS (Tidak setuju atau kurang baik) \\
\hline $40 \%-59.99 \%$ & C (Cukup) \\
\hline $60 \%-79.99 \%$ & S (Setuju, baik atau suka) \\
\hline $80 \%-100 \%$ & SS (Sangat setuju, baik, suka) \\
\hline
\end{tabular}


Berdasarkan data hasil kuesioner, dapat dicari prosentase masing-masing jawaban dengan menggunakan rumus:

Total Skor $=\mathrm{T} * \mathrm{Pn}$

$\mathrm{Y}=$ Skor tertinggi $*$ jumlah responden

Persentase skor $=($ Total skor/Y $) * 100 \%$

Keterangan:

$\mathrm{T}=$ Total Responden yang memilih

Pn $=$ Pilihan angka skor likert

TABEL 4.HASIL PENGUJIAN BETA

\begin{tabular}{|c|c|c|c|c|c|c|}
\hline $\begin{array}{c}\text { Nomor } \\
\text { Pertanyaan }\end{array}$ & STS & TS & C & S & SS & SKOR \\
\hline 1 & 0 & 0 & 0 & 7 & 6 & $89 \%$ \\
\hline 2 & 0 & 2 & 2 & 6 & 3 & $75 \%$ \\
\hline 3 & 0 & 0 & 1 & 7 & 5 & $86 \%$ \\
\hline 4 & 0 & 0 & 1 & 5 & 7 & $89 \%$ \\
\hline 5 & 0 & 0 & 1 & 6 & 6 & $88 \%$ \\
\hline 6 & 0 & 0 & 1 & 5 & 7 & $89 \%$ \\
\hline 7 & 0 & 0 & 3 & 4 & 6 & $85 \%$ \\
\hline 8 & 0 & 0 & 3 & 4 & 6 & $85 \%$ \\
\hline \multicolumn{7}{|c|}{ Hasil rata-rata skor } \\
\hline
\end{tabular}

\section{Analisis Data/Evaluasi}

Setelah pengujian aplikasi maka dilakukan evaluasi untuk mengetahui hasil dari pengujian tersebut. Data pengujian yang telah diperoleh selama pengujian dianalisa dan dijelaskan secara lengkap untuk mengetahui hasil pengujian yang akurat. Berdasarkan data pengujian, pada pengujian alpha terdapat sebuah kesalahan pada user super admin yang tidak dapat melihat profil dan mengubah data profil karena session pada login tidak valid. Selain dari itu tidak ada kesalahan pada fungsi-fungsi di web ini. Testing pada fungsi-fungsi lain dari sistem telah berjalan sesuai dengan requirement yang dibutuhkan sehingga mampu memenuhi penginputan, penyimpanan, dan pengolah data yang diperlukan untuk melakukan promosi kepada pelanggan.

Pada proses pengujian beta aplikasi diberikan ke beberapa orang untuk melakukan penilaian secara subyektif. Pada proses ini semua fungsi sudah berjalan dengan baik dan penilaian hanya dilakukan pada segi kualitas dari web. Berdasarkan hasil pengujian beta desain tampilan dari web Let's Go Outside yang ada pada aplikasi mendapat skor $89 \%$ yang berarti menurut user aplikasi ini sudah sangat baik dalam tampilan. Tipografi dari aplikasi juga sudah baik dengan skor $75 \%$. Untuk kemudahan dalam penggunaan aplikasi juga sudah sangat baik dengan skor $86 \%$. Untuk kecepatan loading aplikasi web sudah sangat baik dengan skor $89 \%$. Informasi yang terdapat di aplikasi sudah sangat baik dengan skor $88 \%$. Menu yang terdapat pada aplikasi web sudah sangat baik dengan skor $85 \%$. Sedangkan peta wisata yang ada pada aplikasi web dan juga form pemesanan yang tersedia pada web mendapatkan skor $85 \%$ yang berarti keduanya sudah sangat baik dan memenuhi kebutuhan pengguna.
Untuk keseluruhan rata-rata persentase skor dari aplikasi adalah $85,7 \%$ yang berarti aplikasi ini masuk dalam kategori sangat baik atau memenuhi apa yang user inginkan. Namun setelah semua dianalisa dan dievaluasi terdapat beberapa hal yang dapat dilakukan untuk meningkatkan kualitas web ini. Pertama yaitu untuk meningkatkan peletakan menu supaya lebih memudahkan pengunjung web dalam memanfaatkan menu-menu yang ada. Menu yang ada dapat berjalan baik ketika diakses melalui komputer atau laptop, akan tetapi masih tidak berjalan dengan baik ketika web diakses melalui smartphone. Kedua adalah untuk meningkatkan fungsi wisata yang ditampilkan pada menu utama supaya dapat menampilkan wisata yang akan segera berakhir masa pemesanannya.

\section{KESIMPULAN}

Dari hasil pengujian alpha ditemukan dua bug dan error pada menu profil, tetapi secara keseluruhan seluruh fungsi pada sistem sudah dapat berjalan dengan lancar, mulai dari sistem login, penambahan informasi wisata hingga konfirmasi pembayaran yang dilakukan oleh user admin dan superadmin. Pengujian alpha juga menjawab keberhasilan untuk memenuhi rancangan awal dengan terdapat pilihan fasilitas tambahan sesuai keinginan pelanggan dan telah berhasil mengirimkan detail pembayaran melalui email pelanggan. Pada pengujian beta, penilaian terhadap sistem secara keseluruhan telah mencapai skor $85,7 \%$ sehingga dapat disimpulkan bahwa sistem ini telah masuk dalam kategori sangat baik atau dapat memenuhi kebutuhan untuk pihak biro travel Let's Go Outside dan juga kebutuhan dari pelanggan.

Aplikasi ini dapat membantu biro travel Let's Go Outside dalam melakukan promosi. Aplikasi web ini juga dapat dijadikan tempat monitoring mengenai pemesanan dan pembayaran tour wisata open trip. Untuk ke depannya, aplikasi ini akan dikembangkan lebih baik lagi dengan menambahkan fungsi login untuk pelanggan dan dashboard pelanggan.

\section{REFERENSI}

[1] Cahyanto, Dwi Budi. 2004. Membangun Aplikasi Handphone Dengan FBUS dan Visual Basic. Yogyakarta: Andi.

[2] Fikri, Azkal. 2010. Aplikasi Short Message Service (SMS) Gateway Untuk Layanan Informasi Registrasi Administrasi Mahasiswa. Jurnal Universitas Pendidikan Indonesia.

[3] Shodiq, Amri. 2008. Pemrograman Google Maps API. Sekolah Tinggi Sandi Negara

[4] Svennerberg, G., 2010. Beginning Google Maps API 3. New York: Apress Media.

[5] M. Syaiful Amri, 2011. Membangun Sistem Navigasi Di Surabaya Menggunakan Google Maps, Politeknik Elektronika Negeri Surabaya, Institut Teknologi Sepuluh Nopember Surabaya

[6] Yoeti, Oka A. 2006. Pemasaran Pariwisata. Edisi Revisi. Bandung:Angkasa 